\title{
The American Dream and Corporate Executive Fraud
}

\author{
Freddie $\mathrm{Choo}^{1}$ and Kim Tan ${ }^{2}$ \\ ${ }^{1}$ Department of Accounting, College of Business, \\ San Francisco State University, San Francisco, CA \\ ${ }^{2}$ Department of Accounting \& Finance, College of Business, \\ California State University Stanislaus, Turlock, CA
}

USA

\section{Introduction}

In this paper, we first describe a "Broken Trust" theory that was introduced by Albrecht el al. (2004) to explain corporate executive fraud. The Broken Trust theory is primarily based on an "Agency" theory from economic literature and a "Stewardship" theory from psychology literature. We next describe an "American Dream" theory from sociology literature to complement Albrecht el al.'s (2004) Broken Trust theory. Like the Broken Trust theory, the American Dream theory relates to a "Fraud Triangle" concept to explain corporate executive fraud in America. We are motivated to explain corporate executive fraud because whenever corporate fraud has been studied, CEOs and CFOs are most involved. For example, the COSO-sponsored study by Beasley et al. (1999) found that CEOs were involved in $72 \%$ of the financial statement fraud cases. The next most frequent perpetrators in descending order of frequency were the controller, $\mathrm{COO}$, vice presidents, and members of the board. In addition, we are motivated to provoke thoughts on corporate executive fraud in American society and to stimulate further empirical research on social variables of executive fraud.

We define "corporate executive fraud" as follows. First, a corporate scandal is a scandal involving allegations of unethical behavior on the part of a company. It follows that a corporate accounting scandal is a scandal involving unethical behavior in accounting, that is, accounting fraud. Accounting fraud includes intentional financial misrepresentations (e.g., falsification of accounts) and misappropriations of assets (e.g., theft of inventory) (AICPA 2002). Intentional financial misrepresentations involving the management of a company are referred to as corporate executive fraud, whereas misappropriations of assets involving the employee of a company are referred to as employee fraud. Taken together, corporate executive fraud is intentional financial misrepresentations by trusted executives of public companies, which typically involve creative methods for misusing or misdirecting funds, overstating revenues, understating expenses, overstating the value of corporate assets, or underreporting the existence of liabilities. 


\section{Theories of corporate executive fraud}

Albrecht el al. (2004) describe a Broken Trust theory to explain corporate executive fraud. It should be noted that they have never used the term "Broken Trust" in their theory. We took the liberty of labeling their theory as the Broken Trust theory. Since Albrecht el al. (2004) derive their Broken Trust theory by linking the Agency theory and Stewardship theory to the Fraud Triangle concept in corporate fraud literature, we first describe the Agency theory, follow by the Stewardship theory, and then the Broken Trust theory. We are aware that research and publication in Agency and Stewardship theories are very extensive, but only those that are specifically related to corporate executive fraud are cited in this paper.

\subsection{Agency theory}

Agency theory was introduced into management literature by Jensen and Meckling (1976). The theme is based on economic theory and it describes a principal-agent relationship between owners (such as stockholders) and executives, with top executives acting as agents whose personal interests do not naturally align with shareholder interests.

The principal-agent relationship involves a transfer of trust and duty to the agent while assuming that the agent is opportunistic and will pursue interests, including executive fraud, which are in conflict with those of the principal. This potential conflict of interests is often referred to as "the agency problem" (Davis et al. 1997). A typical solution to the agency problem is to structure executive incentives, such as stock options, in such ways that they align executive behavior with stockholder goals. Another common solution to the agency problem is for the board of directors to control and curtail the "opportunistic behavior" of the executives by, for example, the audit committee (Donaldson and Davis 1991).

However, the studies cited in Davis et al. (1997) indicate corporate executives are extremely complex human beings and the agency problem persists. Recent studies by Daily et al. (2003) and Sundaramurthy and Lewis (2003) also show that, in practice, corporate executives have power to counteract the board's control over them. For example, the corporate executives can exercise influence over the board because they are more in tune with daily operations of the company, or they exercise influence over succession of the board to ensure that board members who agree with them are appointed. Finally, Bebchuk and Fried (2004) argue that corporate executives' influence over the board of directors on pay setting can explain a wide range of compensation practices and patterns. This includes ones that have long been viewed as puzzles by economists such as why pay is higher and less sensitive to bad performance, including fraud, in corporations in which executives are more entrenched or have more power vis-à-vis the board.

\subsection{Stewardship theory}

In contrast to Agency theory, Stewardship theory is based on psychology theory that views corporate executives as stewards of their companies who will choose the interests of the stockholders over the interests of self, regardless of personal motivations or incentives (Donaldson and Davis 1991; Sundaramurthy and Lewis 2003). Since the executives can be trusted to place stockholder interest first, the board of directors focuses on empowering rather than controlling the executives. Another theory that focuses on empowering the corporate 
executives is Resource Dependency theory (Daily et al. 2003). This theory holds that the board of directors is boundary spanner of the company and its environment. It provides the corporate executives access to resources to which they would not normally have access. For example, a lawyer might be appointed to the board to provide legal advice to the executives.

Like Agency theory, Stewardship theory seeks the alignment of corporate executives with the stockholders interests. Also, like Agency theory, Stewardship theory cannot explain the complex behavior of the executives such as whether they will or will not break the trust and commit fraud. For example, the board's lack of psychological independence from the corporate executives underlying the stewardship relationship may be partly to blame for the executives' fraudulent behavior. Psychology independence refers to the board's lack objectivity both affectively (e.g., directors can be blind sighted by their admiration for the corporate executives' persona) and cognitively (e.g., directors can be blind sighted by their belief in the corporate executives' expertise). A lack of psychological independence is a problem in many boardrooms across corporate America. As pointed out by Lorsch (2005), directors tend to like and admire their corporate executives. They find it hard to penalize their corporate executives even when the company is doing badly and they tacitly tolerate the executives' fraudulent behavior.

\subsection{Broken trust theory}

Since Albrecht et al.'s (2004) Broken Trust theory is related to a "Fraud Triangle" concept from corporate fraud literature, we begin by describing the origin of the Fraud Triangle concept. Much of the current corporate fraud literature is based on the early work of Edwin H. Sutherland (1883-1950), a criminologist at Indiana University. Sutherland (1949) was particularly interested in fraud committed by the elite business executives against stockholders. He coined the term "white-collar crime" to mean criminal acts of corporations and individuals acting in their corporate capacity. One of Sutherland's Doctoral students was Donald R. Cressey (1919-1987). Cressey (1973) was especially interested in the circumstances that led embezzlers, whom he called "trust violators," to be overcome by temptation. His hypothesis about the psychology of the embezzlers was later become known as the "Fraud Triangle" concept, which consists of three variables: perceived financial need, perceived opportunity, and rationalization. In the early 1980s, the Fraud Triangle concept was adapted from criminology to accounting by Steve Albrecht of Brigham Young University. Albrecht was especially interested in identifying factors that led to occupational fraud and abuse. His study suggests that there are three variables involved in occupational fraud. Consistent with Cressey's Fraud Triangle concept: “ ... it appears that three elements must be present for a fraud to be committed: a situational pressure, a perceived opportunity to commit and conceal the dishonest act, and some way to rationalize the act as either being inconsistent with one's personal level of integrity" (Albrecht et al. 1984, p.5). Later, the Statement on Auditing Standards No.99: Considerations of Fraud in a Financial Statement Audit issued by the AICPA (2002) adopted much of Albrecht's work on the Fraud Triangle concept detailed in his book Fraud Examination (2003). The auditing standard also incorporated many fraud risk factors associated with the three variables of the Fraud Triangle concept: (1) a "pressure" such as a financial pressure to meet analysts' expectation, (2) an "opportunity" such as weak internal controls, and (3) some way to "rationalize" such as "our stock options depend on it." 
In 2004, Albrecht et al. combined the Fraud Triangle concept, the Agency theory, and the Stewardship theory to develop a "Broken Trust" theory of corporate executive fraud. Their Broken Trust theory explains corporate executive fraud in a matrix that links the three variables to corporate executive whose behavior is either consistent with the stewardship theory or agency theory; whose corporate structure is either consistent with the stewardship-based structure or agency-based structure, and whose compensation is either consistent with the stewardship-based rewards and incentives or agency-based rewards and incentives. We summarized their matrix in Table 1. Albrecht et al. conclude that, "to a meaningful degree, executives self-identify with behavior either more consistent with the agency theory or stewardship theory of management, and that those whose behavior is, in fact, more consistent with stewardship theory are more trustworthy and generally less likely to commit fraud" (2004, p.109). A tenet of Albrecht et al.'s Broken Trust theory is that both the Agency theory and Stewardship theory share a common element, "transference of some measure of trust from shareholders to executive level managers," and when executives commit fraud they intentionally break the trust and betray shareholders.

\begin{tabular}{|l|l|l|}
\hline Fraud Triangle Concept & Broken Trust Theory & American Dream Theory \\
\hline Pressure & $\begin{array}{l}\text { Pressure to commit fraud } \\
\text { leads corporate executives } \\
\text { to break their agency or } \\
\text { stewardship relationship. }\end{array}$ & $\begin{array}{l}\text { An intense emphasis on monetary } \\
\text { success induces corporate } \\
\text { executive fraud. }\end{array}$ \\
\hline Opportunities & $\begin{array}{l}\text { Corporate executives have } \\
\text { opportunities to break } \\
\text { their agency or } \\
\text { stewardship relationship. }\end{array}$ & $\begin{array}{l}\text { Corporate executives } \\
\text { exploit/disregard regulatory } \\
\text { controls to commit fraud. }\end{array}$ \\
\hline Rationalization & $\begin{array}{l}\text { Corporate executives are } \\
\text { inclined to rationalize their } \\
\text { fraudulent actions and } \\
\text { behavior. }\end{array}$ & $\begin{array}{l}\text { A corporate environment that is } \\
\text { preoccupied with monetary } \\
\text { success provides } \\
\text { justification/rationalization for } \\
\text { success by deviant means such as } \\
\text { fraud. }\end{array}$ \\
\hline
\end{tabular}

Table 1. The Fraud Triangle Concept, Broken Trust Theory, and American Dream Theory

We next describe an "American Dream" theory from sociology literature as a complement to Albrecht el al.'s Broken Trust theory because we believe the Broken Trust theory has two key limitations. First, a vast majority of management research in Agency and Stewardship theories addresses executive behavior in stable or growing companies, but not in companies involved in fraud (Daily et al. 2003). Therefore, the Broken Trust theory, based on the 
Agency and Stewardship theories, assumes it can explain executives' fraudulent behavior in both fraud and non-fraud companies. Such assumption is weak given that there is very little evidence in the Agency and Stewardship theories that addresses executive behavior in companies involved in fraud.

Second, we believe the Broken Trust theory relate well to the first two variables (Pressure and Opportunity) of the Fraud Triangle concept, but not the third variable (Rationalization) because Albrecht et al. (2004, Table 3, p.127) provide very little explanation on why or how the corporate executives would rationalize their fraudulent behavior under the Broken Trust theory.

\section{Origin of the American Dream theory}

The term "the American Dream" was introduced into contemporary social analysis in 1931 by historian James Truslow Adams to describe his vision of a society open to individual achievement. Interestingly, Adams sought to have his history of the United States, Epic of America, entitled The America Dream, but his publisher rejected the idea, believing that during the Great Depression, consumers would never spend three dollars "on a dream." (Adams 1931, p.68). The term soon became a sales slogan for the material comforts and individual opportunities of a middle-class lifestyle: a car, a house, education for the children, and a secure retirement.

The persistence of the term "the American Dream" over subsequent decades is documented in the work of Elizabeth Long, who has analyzed cultural changes in the United States during the years following World War II. Long examines the shifting meanings of the dream of success as reflected in best-selling novels published between 1945 and 1975. She concludes that the core components of the American Dream were reflected in popular writings throughout the thirty-years period following World War II (Long 1985, p.196).

An "American Dream" theory of crime in the United States was introduced into contemporary sociology by Messner and Rosenfeld (1994). They developed the American Dream theory as an extension to the "Anomie" theory associated with the work of the American sociologist Robert K. Merton (1938). A central idea of Merton's Anomie theory is that motivations for crime do not result simply from the flaws, failures, or free choices of individuals. A complete explanation of crime ultimately must consider the sociocultural environments in which people conduct their daily lives. Merton argues that the social system in the United States is a prime example of a system characterized by internal strain and contradictions. Specifically, Merton observes that an exaggerated emphasis is placed on the goal of monetary success in American society, coupled with a weak emphasis placed on the importance of using the socially acceptable means for achieving this goal. We realize that American capitalism put emphasis on socially acceptable means for financial success, such as competition. In addition, American education system put some emphasis on socially acceptable means for financial success, such as collaboration. However, as pointed out by Merton (1938), a key issue here is the exaggerated emphasis on financial success in a capitalist society that leads to socially unacceptable means. The result of these sociocultural environments is a pronounced strain toward anomie, that is, a tendency for social norms to 
lose their regulatory force. Originally, an 18th century French sociologist, Emile D. Durkheim, defined the term "anomie" as a condition where social and/or moral norms are confused, unclear, or simply not present. Durkheim felt that this lack of norms - or preaccepted limits on behavior in a society - led to deviant behavior such as individual suicide or executive fraud (Giddens 1972, p.184 - in The Division of Labor in Society translated by George Simpson). Later, Richard Cloward and Lloyd Olin (1960) expanded Merton's Anomie theory to include circumstances that provide the opportunity for people to acquire through illegitimate activities, such as gang activities, what they cannot achieve through accepted methods.

Messner and Rosenfeld (1994) observe that Merton's Anomie theory does not provide a fully comprehensive sociological explanation of crime in America. They argue that the most conspicuous limitation of Merton's theory is that it focuses exclusively on one aspect of the American social structure: inequality in access to the legitimate means for success. As a consequence, it does not explain how specific features of the broader institutional structure of society interrelate to produce the anomic pressures that are responsible for crime. Messner and Rosenfeld (1994, p.66) developed an institutional anomie theory similar to Merton's and called it the "American Dream" theory with specific reference to four social institutions - the family, the education, the polity (political system), and the economy. The institution of family bears the responsibility for the care of dependent persons and to provide emotional support for its members. The institution of education bears the responsibility for transmitting basic knowledge to new generations and to prepare youth for the demands of occupational roles. The institution of polity bears the responsibility for protecting members of society and to mobilize and distribute power to attain collective goals. Finally, the institution of economy bears the responsibility for the production and distribution of goods and services.

A basic tenet of Messner and Rosenfeld's (1994) American Dream theory is that the pursuit of monetary success (i.e., the institution of economy) has come to dominate the American society, and that the non-economic institutions (i.e., the institution of education, the institution of polity, and the institution of family) have tended to become subservient to the economy. For example, the entire educational system seems to have become driven by the job market, politicians get elected on the strength of the economy, and despite lip service to family values, executives are expected to uproot their families in service to corporate life. Goals other than material success, such as teaching, are missing from the portrait of the American Dream, as reflected in the old adage "Those who can, do; those who can't, teach" (Long 1985, p.196).

Messner and Rosenfeld's (1994) American Dream theory points to a broad cultural ethos in which the goal of monetary success is to be pursued by everyone in a mass society dominated by huge multinational corporations. As they observe: “Given the strong, relentless pressure for everyone to succeed, understood in terms of an inherently elusive monetary goal, people formulate wants and desires that are difficult, if not impossible, to satisfy within the confines of legally permissible behavior" (1994, p.77). This key feature of the American Dream helps explain corporate fraud that offers monetary success to corporate executives. Moreover, the distinctive cultural message accompanying the monetary success 
goal is to pursue the American Dream by "any means necessary." This anomic orientation of the American Dream helps explain top executives' tacit approval of corporate fraud. ${ }^{1}$

We caution against an overly simplistic interpretation of American culture. The United States is a complex and, in many respects, culturally pluralistic society. It neither contains a single, monolithic value system nor exhibits complete consensus surrounding specific value issues. We nevertheless concur with Hochschild's (1995, p.xi) that the American Dream has been, and continues to be, a "defining characteristic of American culture," a cultural ethos "against which all competitors must contend." In addition, we believe a better understanding of corporate executive fraud is possible by relating three key features of the American Dream theory (Intense emphasis on monetary success, Corporate executives exploit/disregard regulatory controls, and Corporate executives justify/rationalize fraudulent behavior) with the three variables of the Fraud Triangle concept (Pressure, Opportunity, and Rationalization).

\section{The American Dream theory and Fraud triangle concept}

\subsection{An intense emphasis on monetary success (Pressure)}

An intense emphasis on monetary success in the corporate environment, which promotes productivity and innovation, also induces fraud by corporate executives. Messner and Rosenfeld (1994, p.8) argue that monetary success, which is responsible for the impressive accomplishments of American society, is also responsible for generating strong pressures to succeed in a narrowly defined way and to pursue such success by "any means necessary" including fraud. In other words, while monetary success has provided the motivational dynamic for entrepreneurship, corporate expansion, extraordinary technological innovation, and high rates of social mobility, it also has provided the motivational dynamic for greed, corporate fraud, unethical behavior, and illegal act. ${ }^{2}$

\subsection{Corporate executives exploit/disregard regulatory controls (Opportunities)}

An intense emphasis on monetary success leads to a pronounced strain toward anomie, that is, a tendency for corporate executives to exploit/disregard regulatory controls for monetary gains. The American Dream embodies the basic value of materialism that has been described as "fetishism of money" (Taylor et al. 1973, p.94). We realize that Americans are not uniquely materialistic, for a strong interest in material well-being can be found in most societies. Rather, the distinctive feature of American culture is the preeminent role of money as the "metric" of success. Orru succinctly expresses the idea in the following terms: "Money is literally, in this context, a currency for measuring achievement" (1990, p.235). This monetary value orientation contributes to the anomic character of the American Dream:

\footnotetext{
${ }^{1}$ We should clarify that anomie is not only engendered by 'limited access' of social actors (i.e., CEOs) to legititmate means of achieving goals. Rather, deviance becomes a tempting and a viable option given the 'limited availability' of legitimate means, which is probably the critical reason why social actors resort to different means not only with the end of achieving the goals, but to "lighten the pressure" of attaining socially sanctioned goals (e.g., money, success, material opulence).

${ }^{2}$ Keane (1993) found some evidence of a latent relationship between corporate pressure to maximize financial performance and corporate crime.
} 
its strong emphasis on the importance of accumulating monetary rewards with its relatively weak emphasis on the importance of following legitimate rules and regulations to do so. In other words, corporate executives seek opportunities to exploit/disregard normative rules and regulations when these rules and regulation threaten to interfere with the realization of their monetary success.

\subsection{Corporate executives justify/rationalize fraudulent behavior (Rationalization)}

A corporate environment that is preoccupied with monetary success, and that implicitly or explicitly allows corporate executives to exploit/disregard regulatory controls, also provides justification/rationalization for success by any means such as fraud. In this regard, the American Dream is a mixed blessing, providing justification/rationalization for both the best and the worst elements of the American character and society (Messner and Rosenfeld 1994, p.7), or in the words of sociologist Robert K. Merton, "A cardinal American virtue, 'ambition,' promotes a cardinal American vice, 'deviant behavior'" (Merton 1968, p.200). ${ }^{3}$ Since monetary success is inherently open-ended, that is, it is always possible in principle to have more money; the American Dream offers "no final stopping point," and it requires "never-ending achievement." (Passas 1990, p.159). Therefore, the desire to accumulate money is relentless; it entices corporate executives to pursue their monetary goals by any means necessary and provides justification/rationalization for their monetary success by deviant means such as fraud.

\section{Conclusion}

To conclude, the three key features of the American Dream theory - Intense emphasis on monetary success, Corporate executives exploit/disregard regulatory controls, and Corporate executives justify/rationalize fraudulent behavior - have their institutional underpinnings in the capitalist economy of the United States. What is distinctive about the capitalist economy of the United States, however, is the exaggerated emphasis on monetary success, which overwhelms other corporate goals and becomes the principal measuring rod for success. The resulting proclivity and pressures to perform induce corporate executives to exploit rules and regulations that stand in the way of corporate success, and at the same time provides rationalization for their non-compliance with rules and regulations. We believe the exaggerated emphasis on monetary success incorporated in American Dream will continue to be a catalyst for fraud by corporate executives in the United States. As such, we wrote this paper to provoke thoughts on corporate executive fraud in American society and to stimulate further empirical research on social variables of executive fraud.

\section{References}

Adams, J. T. 1931. The Epic of America. Boston: Little, Brown.

\footnotetext{
${ }^{3}$ In Merton's subsequent publications and personal interviews, he reiterated that his notion of "deviant behavior" did not explicitly relate to individual level cognition; rather, it was implicitly related to individual cognitive behavior, such as justification, neutralization, and rationalization, as a consequent of external structural forces that impressed themselves upon individual human conduct.
} 
AICPA (2002). Statement on Auditing Standards No.99: Considerations of Fraud in a Financial Statement Audit. Appendix : 306-3010.

Albrecht, W.S. 2003. Fraud Examination. Southwestern/Thomson.

Albrecht, W.S., C.C. Albrecht, and C.O. Albrecht. 2004. Fraud and corporate executives: Agency, stewardship and broken trust. Journal of Forensic Accounting 5: 109-130.

Albrecht, W.S., K.R. Howe, and M.B. Romney. 1984. Detecting Fraud: The Internal Auditor's Perspective. Altamonte Springs: The Institute of Internal Auditors Research Foundation.

Beasley, M.S., J.V. Carcello, and D.R. Hermanson. 1999. Fraudulent Financial Reporting: 19871997: An Analysis of U.S. Public Companies, Committee of Sponsoring Organizations (COSO).

Bebchuk, L.A. and J.M. Fried. 2004. Pay Without Performance: The Unfulfilled Promise of Executive Compensation. Harvard University Press.

Cloward, R., and L.E. Ohlin, 1960. Delinquency and Opportunity: A Theory of Delinquent Gangs. Glencoe, Ill.: Free Press.

Cressey, D.R. 1973. Other People's Money. Montclair: Patterson Smith.

Daily, C.M., D.R. Dalton, and A.A. Canella Jr. 2003. Corporate governance: Decades of dialogue and data. Academy of Management Review 28: 371-383.

Davis, J.H., F.D. Shoorman, and L. Donaldson. 1997. Toward a stewardship theory of management, The Academy of Management Review 22.

Donaldson, L. and J.H. Davis. 1991. Stewardship Theory. Australian Journal of Management 16.

Giddens, Anthony (ed). 1972. Emile Durkheim: Selected Writings. London: Cambridge University Press.

Hochschild, J. 1995. Facing Up to the American Dream: Race, Class, and the Soul of the Nation. Princeton, NJ: Princeton University Press.

Jensen, M.C. and W.H. Meckling. 1976. Theory of the firm: Managerial behavior, agency costs, and ownership structure. Journal of Financial Economics 3: 305-360.

Keane, C. 1993. The impact of financial performance on frequency of corporate crime: A latent variable test of strain theory. Canadian Journal of Criminology 35(3): 293-308.

Long, E. 1985. The American Dream and the Popular Novel. Boston: Routledge \& Kegan Paul.

Lorsch, J. W. 2005. Viewpoints posted on the Harvard Business School's Corporate Governance, Leadership \& Values website: http://www.cglv.hbs.edu/December 2005.

Merton, R.K. 1938. Social structure and anomie. American Sociological Review 3: 672-682

Merton, R. K. 1968. Social Theory and Social Structure. New York: Free Press.

Messner, S. and R. Rosenfeld, R. 1994. Crime and the American Dream. Belmont: Wadsworth.

Orru, M. 1990. Merton's instrumental theory of anomie, in Robert K. Merton: Consensus and Controversy, edited by Clark, Modgil, and Modgil. London: Falmer.

Passas, N. 1990. Anomie and corporate deviant. Contemporary Crises 14: 157-178.

Sundaramurthy C. and M. Lewis. 2003. Control and collaboration: Paradoxes of government. Academy of Management Review 28: 397-416.

Sutherland, E. H. 1949. White-Collar Crime. New York: Dryden Press. 
Taylor, I., P. Walton, and J. Young. 1973. The New Criminology: For a Social Theory of Deviance. New York: Harper \& Row. 


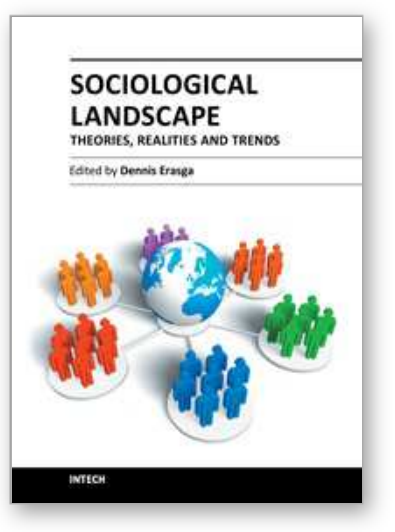

\author{
Sociological Landscape - Theories, Realities and Trends \\ Edited by Dr. Dennis Erasga
}

ISBN 978-953-51-0460-5

Hard cover, 428 pages

Publisher InTech

Published online 28, March, 2012

Published in print edition March, 2012

More than the usual academic textbook, the present volume presents sociology as terrain that one can virtually traverse and experience. Each version of the sociological imagination captured by the chapter essays takes the readers to the realm of the taken-for-granted (such as zoological collections, food, education, entrepreneurship, religious participation, etc.) and the extraordinary (the likes of organizational fraud, climate change, labour relations, multiple modernities, etc.) - altogether presumed to be problematic and yet possible. Using the sociological perspective as the frame of reference, the readers are invited to interrogate the realities and trends which their social worlds relentlessly create for them, allowing them in return, to discover their unique locations in their cultures' social map.

\title{
How to reference
}

In order to correctly reference this scholarly work, feel free to copy and paste the following:

Freddie Choo and Kim Tan (2012). The American Dream and Corporate Executive Fraud, Sociological Landscape - Theories, Realities and Trends, Dr. Dennis Erasga (Ed.), ISBN: 978-953-51-0460-5, InTech, Available from: http://www.intechopen.com/books/sociological-landscape-theories-realities-and-trends/theamerican-dream-and-corporate-executive-fraud

\section{INTECH}

open science | open minds

\section{InTech Europe}

University Campus STeP Ri

Slavka Krautzeka 83/A

51000 Rijeka, Croatia

Phone: +385 (51) 770447

Fax: +385 (51) 686166

www.intechopen.com

\section{InTech China}

Unit 405, Office Block, Hotel Equatorial Shanghai

No.65, Yan An Road (West), Shanghai, 200040, China

中国上海市延安西路65号上海国际贵都大饭店办公楼 405 单元

Phone: +86-21-62489820

Fax: +86-21-62489821 
(C) 2012 The Author(s). Licensee IntechOpen. This is an open access article distributed under the terms of the Creative Commons Attribution 3.0 License, which permits unrestricted use, distribution, and reproduction in any medium, provided the original work is properly cited. 